\title{
Premontrei prépostságok a középkori Magyarországon, különös tekintettel a Kaposföi Szent Benedek prépostságra
}

\author{
ARADI CSILLA \\ KJH, Járási Építésügyi és Örökségvédelmi Hivatal, H-7400 Kaposvár, Csokonai u. 3., e-mail: csiaradi@freemail.hu
}

ARAdI, Cs.: Premonstratensian monasteries in medieval Hungary with special regards to the S. Benedict provostry of Kaposfö.

Abstract: The paper deals with the diffusion of Premonstratensian monasteries in Hungary, their relations and the role they played in pastoral life. It also gives a brief insight into the only Norbertine foundation in Somogy county (Kaposfö).

Keywords: abbey, cura animarum, filial connections, monument and archaeological research, Moys, ground penetrating radar

\section{A premontrei prépostságok magyarországi elterjedése, jellemzői}

A magyarországi premontrei prépostságok történetének első nagy összefoglalása Oszvald Ferenc Arisztid, premontrei szerzetestanár jóvoltából látott napvilágot, először 1939-ban, majd pedig kibővítve 1957-ben. ${ }^{1}$ A következő nagyobb, többek között a norbertinusok magyarországi történeti és műemléki hagyatékával is foglalkozó kiadványra 2002-ig kellett várni, ${ }^{2}$ bár vitathatatlanul születtek kisebb összefoglalók, 1-1 monostorral foglalkozó kutatási jelentések, recenziók a köztes időszakban is. ${ }^{3}$

Az 1120-ban Szt. Norbert ${ }^{4}$ által alapított kanonok-

1 Oszvald Ferenc Arisztid: A magyarországi premontrei prépostságok. Budapest 1939., Oszvald Ferenc: Adatok a magyarország premontreiek Árpád-kori történetéhez. In: Müvészettörténeti Értesítö 1957. 231-254

2 Kovács Imre Endre-Legeza László: Premontreiek (Szerzetesrendek a Kárpát medencében). Budapest 2002.

3 A teljesség igénye nélkül: Valter Ilona: Zsámbék (Újabb régészeti kutatások a Zsámbéki premontrei prépostsági romban 19861991. Múemlékvédelmi Szemle 1991. 2. 24-28.), Lukács ZsuzsaJuan Cabello-Csengel Péter: Ócsa (Az Ócsai premontrei prépostság kutatása, Múemlékvédelmi Szemle 1991. 1. 16-19.), Kozák Károly: Mórichida (A premontreiek építkezései Györ-Sopron megyében, Arrabona 1973. 125-148.), Jánoshida (A jánoshidai rk. templom, volt premontrei prépostság régészeti kutatása 19701974, Jász Múzeum Jubileumi Emlékkönyve, Jászberény, 1974. 277-322.), Pámer Nóra: Gyulafirátót (A gyulafirátóti középkori premontrei monostor feltárása VMMK. 1967. 239-246.), Csengel Péter (Juan Cabello): Majk (A majki premontrei prépostság feltárása. Müemlékvédelmi Szemle 1991. 2. 44-46.), Alojz Habovstiak: Bény (Frühmittelalterliche Wallanlage und romanische Bauten in Bina. Nyitra, 1966)

4 Szt. Norbert (1080-1134), Genep várurának fia, már fiatalon Xanten város társaskáptalanjának tagja lett, majd Henrik császár udvari kancellárjaként tevékenykedett. Az egyházi karrier lehetöségét félredobva, pappá szentelése után felkereste II. Gelasius pápát, akitől vándorprédikátori engedélyt kapott. Végül 13 társával Prémontrében telepedett le. 1126-ban II. Honorius pápa engedélyezte a rend müködését, ugyanebben az évben Norbertet Magdeburgi érsekévé választották. Maradványai a prágai Strahov premontrei monostorban találhatók. rend a hagyomány szerint már II. István király (11161131) idejében megjelent Magyarországon. Elsőként a királyi alapítású, a Prémontréi anyamonostor fíliájaként létrehozott váradhegyfoki prépostsággal (1130 körül $)^{5}$, míg utolsókét az ugyancsak uralkodói akaratból létesített Csuti apátsággal (1264) együtt, összesen közel 40 magyarországi házzal számolhatunk az Árpád-korban. Míg a korai korszakban - az ún. Ninivei katalógus kibocsájtását megelőzően főleg az ország É.-i, ÉK.-i részein létesültek nagyobb számban prépostságok, a második korszakban már általánosan elterjedtté váltak, sőt több esetben korábbi bencés monostorokat alakítottak át premontreivé (Almás, Bény, Bozok, Meszes, Somlóvásárhely). Közkedveltségük nem meglepő, hiszen a rend tagjai reguláris kanonokok voltak, akik Szent Ágoston regulája szerint, a szerzetesi életforma mellett lelkipásztorkodással is foglalkoztak. Monostoraikhoz akár nagyszámú plébánia is tartozhatott, illetve hiteleshelyi funkciókat is elláthattak. ${ }^{6}$ A hiteleshelyi gyakorlatot a későbbiekben a csökkent létszámú konventek tekintetében megszüntették, így a középkor végén már csak Csorna, Jászó, Lelesz, Ság és Túróc látott el ilyen tevékenységet. ${ }^{7}$ Ebböl az adatból is szembetünő a kanonokrendek háttérbe szorulása a későközépkor folyamán. A 15. században több prépostság beszüntette müködését, Zsámbék pedig a pálosoké lett. 1506-ban Fegyverneky Ferenc sági prépost és Majthényi Uriel túróci kommendátor prépost kezdeményezésével egy reformmozgalom vette kezdetét, amely céljai között a szabad prépostválasztás is szerepelt, amely azonban Bakócz Tamás esztergomi érsek kedvező fogadtatása, valamint a leleszi

5 Az 1130-as alapítás helyett több kutató egy 1160-70 körüli alapítást tart valószínünek, annak ellenére, hogy a Képes Krónika megemlékezik II. István váradi temetkezéséröl (premontrei szerzetesi köntösbe öltözött - uralkodásának tizennyolcadik évében Váradon temették el). A prépostságot említő első biztos forrás 1234-böl származik, amikor András kanonok szertartáskönyvekért Prémontréba látogatott. Közvetett bizonyítékok szólnak azonban a korai alapítás mellett, mivel 1149-ben Havelbergi Anzelm Dialogi címü munkájában - amelyet II. Jenő pápának küldött - Magyarországot is megemlíti azon országok körében, ahol premontreiek vannak. Kovács-Legeza 2002. 17-18.

6 Kovács-Legeza 2002. 21. Az 1231 évi XXI. tcikk nevesítette a káptalanok és konventek - köztük a premontreiek - hiteleshelyi funkcióját.

7 Kovács-Legeza 2002. 22-23. Az 1351 évi III. tcikk a minimálisan 12 fövel, míg az 1492. évi XLIV törvény a 7 papi rendtaggal rendelkező konventek esetében adott engedélyt a hiteleshelyi tevékenység végzéséhez. A prépostságok közti különbségeket jól szemlélteti az 1396. évi rendelet, amely a török elleni hadjárat finanszírozására taxafizetésre kötelezte a premontreieket is, míg Túróc 270, addig Hatvan csak 20 arany Ft-ot fizetett. 
és jászói házak csatlakozása ellenére sem vezetett sikerre. E reformtörekvésekhez kapcsolódóan kerültek 1511-ben a szegedi Szentlélek monostor apácái Somlóvásárhelyre, ahová magukkal vitték kódexeiket is. ${ }^{8}$ A 16 . században a még müködő 17 prépostságból 7-t a török pusztított el, 10-ben pedig magától szűnt meg a monasztikus életforma.

Bár Norbert, a rend alapítója jó barátságban volt Clairvaux-i Szent Bernáttal, és a ciszterci eszmék, mind rendi életmódjukban, mind a kormányzás területén befolyást gyakoroltak a premontreiekre, a norbertinusok, a későbbi koldulórendek előfutáraiként, apátságaikat városok, vagy forgalmas helyek közelében emelték. Vásáros helyen találhatjuk a Somlóvásárhely apácakolostort, közlekedési csomópontokban létesült Hatvan, Csorna, Türje, Zsámbék, (Ipoly)Ság, Váradhegyfok monostora, míg átkelőhelyeknél a Jánoshidai, Mórichidai, Bényi és a Margitszigeti apátság. ${ }^{9}$ Kezdetektől fogva alapítottak apátságokat már meglévő plébániatemplomok szomszédságában, így a 14-15. századra a plébániai megbízás általános gyakorlattá vált.

A lelkipásztorkodásban való részvétel sok esetben szemet szúrt a megyéspüspököknek, és gyakorta konfliktushoz vezetett, hiszen a tizedszedés elmaradása anyagi szempontból, míg az egyházmegyei zsinatokon való részvétel hiánya pedig igazgatási szempontból okozott gondot. Ugyan a premontrei rend már II. Ince pápa (1130-1143) alatt megkapta a tizedfizetéssel kapcsolatos mentességet, és annak jogát, hogy saját területén kápolnát állíthat és benne misét celebrálhat, 1273-ban a hatvani premontreiek bepanaszolják Lampert egri püspököt, aki zaklatásnak teszi ki parochiális egyházukat, és tizedfizetésre kényszeríti őket. ${ }^{10}$ III. Lucius pápa 1184-ben elődje engedélyét megújította és szabályozta oly módon, hogy a plébániákra kihelyezett kanonokot be kell mutatni a megyés püspöknek, aki lelki értelemben gyakorolhatta felette a joghatóságot. ${ }^{11}$ Mivel a szerzetesrendek jövedelemforrást is láttak a plébániákban, törekedtek azok megszerzésére, illetve megtartására, nem egy esetben pedig kisegítőként a 13. század végéig világi papokat is alkalmaztak. 1297-ben József szentendrei főesperes panaszkodik a margitszigeti premontreiekre, hogy az ő népének szentségeket szolgáltatnak ki. ${ }^{12}$ 1388-ban a leleszi konvent munkájába kívánt István egri püspök beavatkozni, és rábírni, hogy az egyházmegyei zsinaton vegyenek részt és ismerjék el joghatóságát maguk fölött. Ennek oka, hogy a monostori egyház a település plébániatemplomaként is funkcionált, szentségeket szolgáltattak ki és a templom körüli temetőbe temették a híveket. Hasonló módon látott el a plébániai funkció-

8 Kovács-Legeza 2002. 30. Apor, Lányi, Pozsonyi és Szegedi (Liber variarum Cantionum) kódex. A kódexeket az apácák a török elöl előbb Bécsbe menekítették, majd az utolsó apátnő halálakor a pozsonyi klarisszákhoz kerültek. Bár a magyar norbertinus apátságoknak a Prémontrében kialakult liturgiát kellett követniük, a 15. század közepétöl a magyar szentek ünnepei is tért hódítottak.

9 Mezey 1963. 15.

10 CD V/2. 82., VII/5. 400

11 Kovács-Legeza 2002. 16.

12 HO V. 82 kat a nemzetségi monostorként alapított Adony, ahová az atyaapát (jelen esetben Lelesz) küldött ki szerzetest, aki immár préposttá lévén vezette a település lelki életét. ${ }^{13}$ Más adatok arról szólnak, hogy a prépostságok nem csak saját monostori templomukban, hanem az általuk telepített falvakban is elláttak plébánosi teendőket.

$A z$ egyes premontrei prépostságok, a könnyebb kormányzás érdekében területi egységeket, ún. circariákat alkottak. A generális káptalan által kiküldött vizitátorok 1200-tól évenként ellenőrizték az 1-1 circáriába tartozó monostorokat a rendi fegyelem megtartása és a rendi adók megfizetése ügyében, amiröl Prémontréban több katalógus is fennmaradt. A legkorábbi, az 1234 évi ninivei katalógus 2 női monostorral együtt Magyarországon 22 prépostságot vett nyilvántartásba. A hilgentali és tongerloi katalógusokból (1294) már kimarad a tatárjárás során elpusztult 4 monostor, azonban számuk kibővül az újabb alapításokkal, míg az 1320-ra elkészült jegyzék őrzi a végleges 39 prépostság nevét. Az összesen 30 circaria közül a 25. volt a circaria Hungariae, amely a középkoron át megőrizte önállóságát. ${ }^{14}$

III. Ince pápa (1198-1216) „In eminenti” kezdetű bullájában szabályozta a rend életét, a prépostoknak az évenként megtartandó generális káptalanon való kötelező részvételét, ami alól csak a nagy távolság jelentett mentséget (ezzel a joggal a magyarországi alapítások több ízben éltek).

\section{Filiáció, titulusadás - a magyar premontrei prépostságok kapcsolatrendszere}

Ugyancsak szoros kapcsolat alakult ki a filiáció révén. Magyarországon 4 olyan prépostságot ismerünk, amely közvetlenül Prémontréből népesült be (Váradhegyfok, Lelesz, Sanctus Augustinus és Túróc). Váradhegyfoknak, mint a premontreiek magyarországi főmonostorának 13 filiája létezett. Váradhegyfokon kívül még a Csornai és a Jászói apátság rendelkezett jelentősebb számú leányegyházzal. ${ }^{15} \mathrm{Ha}$ megürült egy filiális egyház préposti állása, akkor az anyamonostor tagjai választották meg az utódját (pl. Bényben 1445ben a sági prépost és konventje gondoskodik a tisztség betöltéséről), birtokeladáskor pedig az atyaapát beleegyezésére is szükség volt. ${ }^{16}$ Gyakori eset, hogy kisebb monostorok prépostjai nagyobb monostorok tagjaivá váltak, így fordulhatott elő, hogy 1343-ban, Péter kaposfői prépost, a leleszi konvent megbízottjaként járt el, míg 1362-ben a leleszi prépost megbízásából tárgyalt a margitszigeti prépost János budai építésszel a leleszi templom tornyának kiépítéséről. ${ }^{17}$

\footnotetext{
13 Oszvald 1957. 232 .

14 Oszvald 1939. 3

15 Csorna filiái: Mórichida, Rajk, Türje, Jászóé: Rátót, Garáb, Ócsa, Darnó.

16 Oszvald 1957. 233, Oszvald 1939. 10. 1281-ben Garáb esetében a Kökényesi, míg 1286-ban Jászó esetében a Váradhegyfoki prépost adta hozzájárulását a birtokelidegenítéshez.

17 Oszvald 1939. 10, 12
} 

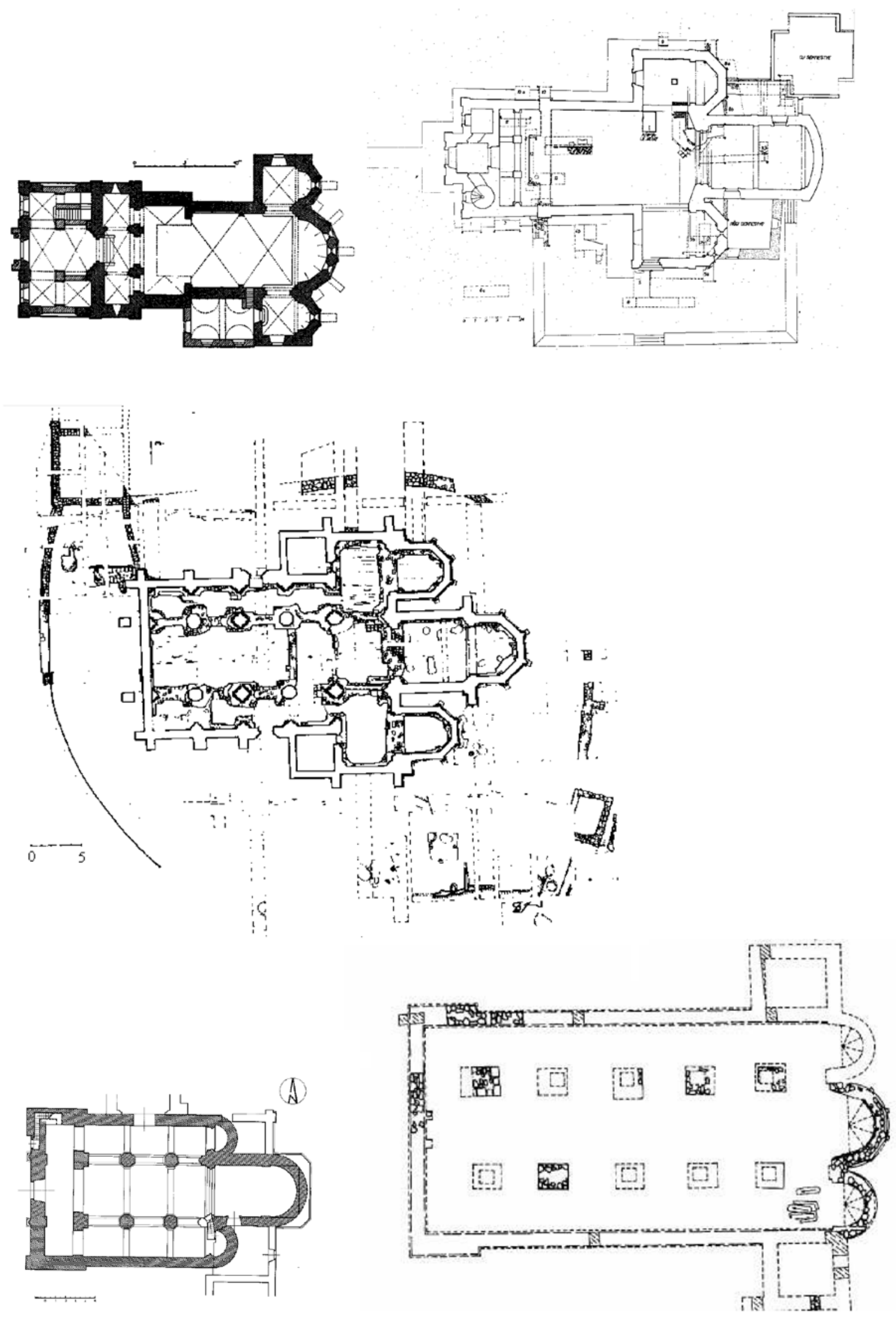

1. ábra. Premontrei prépostságok megkutatott alaprajzai l.: Bény, Jánoshida, Ócsa, Türje, Majk 

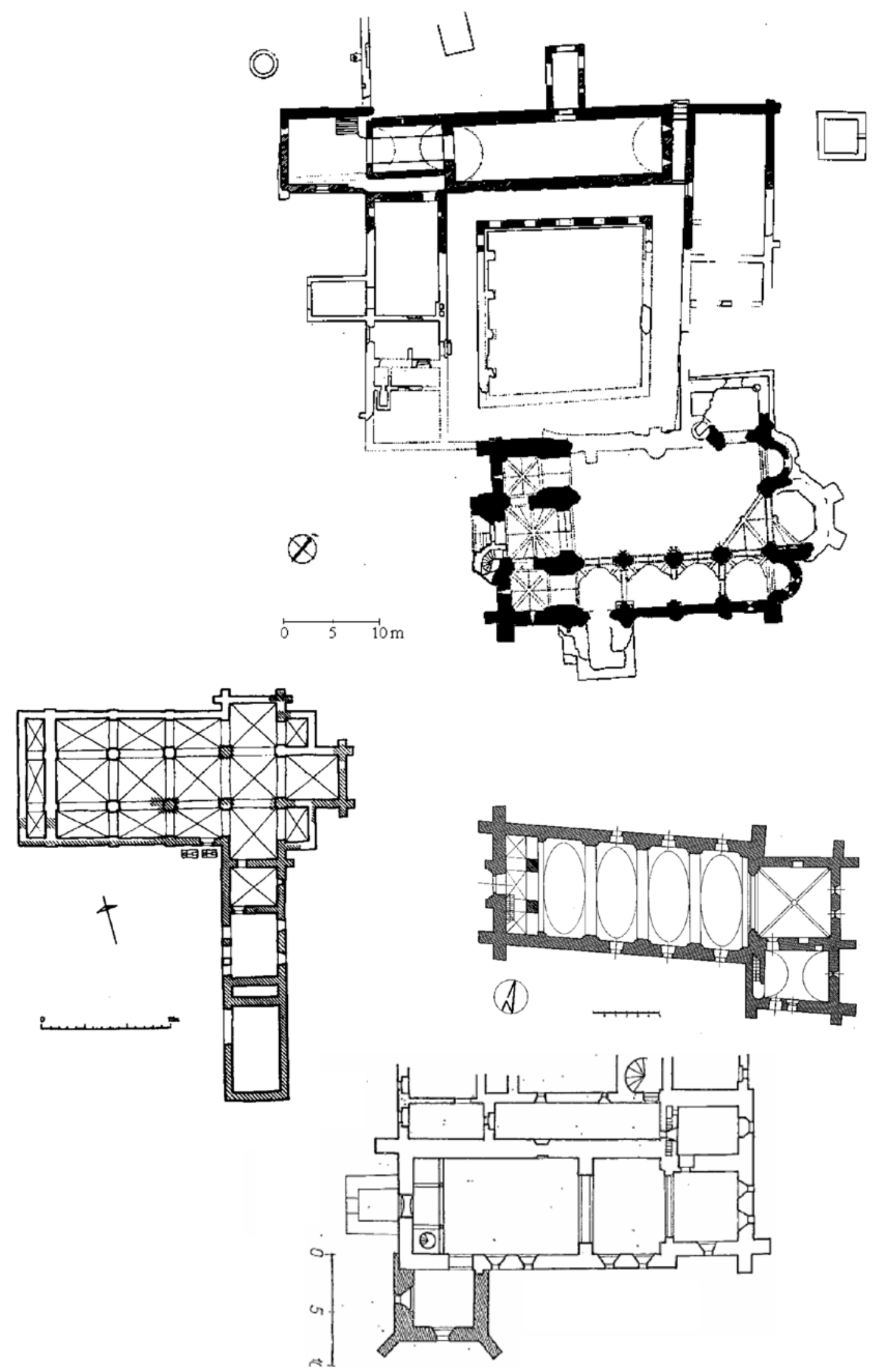

2. ábra. Premontrei prépostságok megkutatott alaprajzai II.: Zsámbék, Gyulafirátót, Mórichida, Túróc 
A titulusadásban a ciszterciekhez hasonlóan Szüz Mária tiszteletére szentelték templomaik többségét, amit az ismert titulusok közel fele (14) esetében lehetett megfigyelni. A 14 féle titulusadásnál az is szembeötlő, hogy a korai alapítások jóval változatosabbak, míg a 13. sz. első felében egységesebbé vált a gyakorlat.

A bizonyítottan királyi alapítások (Váradhegyfok, Jászó, Margitsziget, Túróc, Csút) a II. István és IV. Béla közti időszakot ölelik fel. A föurak körében a 12. század második felében a Hont-Pázmány nembeliek (Ság, Bozók) és a Kökényes-Radnót nemzetség egyik tagja, Mikud fehárvári prépost tünik ki (Kökényes, Garáb), aki a csornai prépostság alapításánál is közreműködött. Elkülönül egy, a 13. század első felére datálható horizont, mely az udvarban jelentős tisztségeket betöltő főurak alapításait mutatja, köztük Pók nembeli Móric mester (Pók, Mórichida), Rátót nembeli Mátyás esztergomi érsek (Gyulafirátót) és Moys nádor (Kaposfö). ${ }^{18}$ A prépostságok legtöbb esetben az alapító család vagy nemzetség temetkezési helyéül is szolgáltak. A monostor kegyurai ezen kívül részesülhettek a monostornak járó 10-edböl, lelki üdvükért imádkozhattak, misét celebrálhattak, prépostjelöltet prezentálhattak a püspöknek. Az alapításhoz a megyés püspök engedélye mellett megfelelő adomány, vagy jövedelem biztosítására is szükség volt.

$A$ rend építészetének virágkorát Magyarországon a 12-13. században élte. Bár a magyarországi prépostságok nagy része nyom nélkül enyészett el, némely épület megőrződött, így Lelesz gótikus, Jászó, Csorna barokk átépítésben, Türje, Ócsa, Jánoshida, Mórichida és (Kis)Bény románkori köntösben, míg Bozók, Zsámbék, Gyulafirátót romjaiban maradt fenn. Bár a premontrei építészetben nem található meg a ciszterekhez hasonló kötöttség, általánosságban jellemző volt a díszes kapuval rendelkező, kéttornyú nyugati homlokzat illetve a benn helyet kapó karzat. A szerzetesi kórus a szentélyben helyezkedett el, és a monostor felöl is biztosított volt a megközelíthetőség. A monostorok többségében kicsik voltak, alig 6-8 fö szerzetessel rendelkeztek és csak ritkán épült ki a kolostori quadrum.

\section{A magyarországi prépostságok műemléki/ régészeti kutatása, alaprajzi változatossága}

A 18. század végén barokk köntösbe bújtatott Csornát Hatvanból népesítették be, védőszentje Szt. Mihály volt. Alapítása 1180 körülre tehető, alapítói az OsI nemzetség tagjai, István és Lőrinc comes. Az alapítás elömozdítói között tudhatjuk Mikud fehérvári prépostot, aki önmaga is két prépostság alapítója volt, és aki 11761187 között a győri püspöki széket is betöltötte, tehát

18 Pók nembeli Móric mester II. András és IV. Béla alatt töltött be jelentősebb tisztségeket, volt asztalnok, pohárnok, illetve tárnokmester. Bár Rátót nembeli Mátyás esztergomi érsek, aki tanulótársa, majd kancellárja volt Béla hercegnek, a Muhi csatában életét vesztette, a nemzetség több tagja került fontos pozícióba, így IV. Béla és Kun László uralkodása között Rátót nembeli Lóránt többek között asztalnok, pohárnok, országbíró és nádor volt. kihatással lehetett az egyházmegyei alapításokra. ${ }^{19}$ A konvent hiteleshelyi tevékenységet is ellátott. Bár a 13. században a nagyobb prépostságok közé tartozottTürje és Rajk alapításához rendtársakat küldött - 1502ben már csak 2-3 rendtaggal rendelkezett. ${ }^{20}$ 1658-ban új templomot építettek a meglévő romokra és Morva területről újjátelepítették a prépostságot. $A z 1$. periódusú templom Ny.-i előcsarnokkal és toronypárral rendelkezett - az elöcsarnok D.-i falában, egy félköríves fülkében a védőszent domborműve helyezkedett el, míg a korai apátság feltehetően D.-ről épült a templomhoz. A hosszú, támpillérekkel ellátott szentély és a K.-i torony később csatlakozott az épülethez.

A leleszi Szt. Kereszt prépostságot, Prémontré filiáját, mely a középkorban jelentős hiteleshelyként is müködött, 1180-1198 közti időszakban alapította a királyi családhoz tartozó Boleszló váci püspök. Az egyszintes rendházat és a templomot 1210-ben szentelték fel. ${ }^{21} \mathrm{~A}$ kegyúri jogot később a király gyakorolta, azonban 1290-ben IV. László eladományozta a prépostságot a Baksa nemzetségnek, akik a gótikus építkezések során kialakították a mai is látható együttest. Az 1540-es években a hatalmaskodások miatt megerősítették a prépostságot. 1569-1697 között a megüresedett apátság kommendátorok kezére került, mely során több tűzvész is pusztított az épületben, ugyanakkor a korábban fölszintes prépostsági épületre emeleti részt húztak és újabb védművekkel erősítették meg a rendházat. A 18. században az apátsági Szt. Mihály kápolnát átalakították és részben barokkizálták a nagytemplomot. A mai állapotában nyújtott, sokszög szentélyzáródású Ny.-i toronypáros templomhoz É.-ról kiépült quadrum társul. A kápolna D.-i falán Utolsó Ítélet, míg É.-i oldalán Veronika kendő ábrázolás maradványait lehet megfigyelni. A sekrestye DK.-i sarkából nyíló csigalépcsőnél a 19. században még látható volt a Pálóczy Domokos prépost nevével, valamint Árpádházi és Anjou címerrel díszített ajtó.

A jánoshidai prépostsággal kapcsolatban az 1186 körüli alapítást és Jób váci püspök, későbbi esztergomi érsek hatását valószínűsíti a kutatás. A Keresztelő Szt. János tiszteletére szentelt apátság alapítását az is befolyásolhatta, hogy ekkorra már 3 másik prépostság (Hatvan, Garáb, Kökényes) állt a közelben, a Zagyva mentén. A mai plébániatemplom műemléki kutatását Kozák Károly irányításával 1971-73 között végezték, minek során feltárták az egyhajós templom két oldalán található sokszögzáródású kápolnát és az eredetileg hasonló záródású főszentélyt. ${ }^{22} \mathrm{~A}$ bényi templommal megegyező alaprajz francia premontrei gyökereket

19 Kozák 1973. 131. Mikud a párizsi egyetemen tanult, feltehetően itt került először kapcsolatba a premontreiekkel. Részt vett a györi székesegyház építkezéseiben, pl. az É.-i emeletes kápolna kialakításában.

20 Kovács-Legeza 2002. 36. 1508-ban engedélyt szereztek szerzetesek más rendekből történő átvételére.

21 Siska 2001. 289.

22 Kozák 1985.2. 
sejtet. ${ }^{23}$ A múemléki kutatás során kibontották a déli oldalkápolna félköríves, bélletes D.-i kapuját, melyet emberarcot rejtő bimbós fejezetekkel díszítettek. A falkutatás során, másodlagos helyükön előkerültek a nyugati főkapu levéldíszes fejezetei is. A hajó déli falában két félköríves, rézsűs ablakot tártak fel. A kápolnák szentélyeit, kívül és belső oldalán is, a sarkokon bimbós oszlopfejezetekkel díszített faloszlopok tagolták, belül ezek a boltozatot tartó párkányt támasztották meg. A déli kápolnának félköríves diadalívét, félköríves záródású rézsűs ablakát és mellékoltárát is felfedezte a kutatás. Az északi kápolna és a főszentély találkozásánál előkerült dombormű feltehetően Keresztelő Szt. János életéből vett jelenetet ábrázol.

A zsámbéki romtemplom területén, az 1930-as évekbeli kutatást (Lux Kálmán, majd Lux Géza) követően, 1986-1991 között Valter llona végzett hitelesítő feltárásokat. A romterületen, az ásatás során, a korai, félköríves szentélyű falusi templom, majd annak helyére épülő premontrei prépostság, illetve a késő-középkori pálos kolostor maradványait kellett elkülöníteni. A Keresztelő Szt. János tiszteletére emelt premontrei prépostságot, váradhegyfok fíliáját, 1210-20 körül alapító, francia eredetű Aynard nemzetség (Smaragd és Egyed ispán) 1403-ig temetkezőhelyéül is használta. A feltárás igazolta, hogy a korábbi, kisméretű templomot is a kegyúri család építette, mivel egy vörösmárvánnyal fedett falazott sír és egy sziklába vágott sír ehhez a korszakhoz köthető. ${ }^{24} A$ háromhajós, sokszögzáródású főszentéllyel, és félköríves záródású mellékszentélyekkel rendelkező, nyugati toronypáros prépostsági templom a korai templom falait pilléralapozásként felhasználta. Az északi oldalról csatlakozó monostor kerengője teljesen kiépült már a 13. században, bár a nyugati oldalon csak a kerengőt határoló fal állt. A keleti oldalon az emeletes épületrészbe a sekrestyéből vezetett fel csigalépcső. A keleti szárnytól K.-re egy kis gazdasági épületet rögzített a feltárás. Bár korábban a prépostság a jelentősebbek közé tartozott, ${ }^{25}$ 1477-ben a pápai bizottság a prépostságot a szerzetesek hibájából elhanyagolt épületként írja le, amelynek hatására Mátyás király az apátságot a pálosoknak adta, akik gótikus stílusban építették át a kolostort. Ekkor épült ki a quadrum nyugati szárnya és kapott a kerengő gótikus boltozatot.

Az ócsai Szűz Mária prépostságot, mint Jászó filiáját a ninivei katalógus már említi, de biztos alapítóját, alapítási idejét nem ismerjük. Valószínűsíthető, hogy Ócsa is a királyi alapítású monostorok körébe tartozott, mivel Pest megye D.-i területe a 13. sz. ele-

23 A bényi Szűz Mária templom, melyet a II. világháborúban jelentős pusztítások értek, ugyancsak egyhajós, három szentélyfejezetes típus, azonban itt a föszentély apszisa félköríves. A háromhajóssá bővülö, emeleti karzatos, ikertornyos nyugati homlokzat elé épült előcsarnokból nyílik a levéldíszes oszlopfős, bélletes nyugati kapu. A karzat É.-i oldalán helyezkedik el a jól ismert, vadászjelenetet megörökítő oszlopfö. A Hont-Pázmány nemzetséghez tartózó Lampertus comes 1131-ben bencés monostorként alapította, azonban Omodeus comes 1217-ben a premontreieknek adta. Váradhegyfok fíliája volt. Kovács-Legeza 2002. 35. 24 Valter 1991. 25-26.

25 Oszvald 1957. 252. Egy időben 20 rendtárs is lakta. jén királyi birtok volt. A valamikor plébániatemplomi funkciókat is ellátó épület 1560-ban került a reformátusok kezére. Több átépítést és tűzvészt követően a 19-20. század fordulóján történt meg a templom müemléki helyreállítása (Tandor Ottó, majd Foerk Ernő tervei alapján), majd a jelenlegi helyreállítása 19861992 között. ${ }^{26}$ A föszentély falán 1902-ben megtalálták a Maiestas Dominit körülvevő apostolokat, a Szt. Miklóst és Szt. Györgyöt, valamint a presbitérium falán a Szt. László ciklust ábrázoló freskókat. A háromhajós, sokszögzáródású fő- és mellékszentélyes, keresztházas bazilika nyugati toronypárral rendelkezik. A keresztházhoz nyugat felé 1-1 bővítmény (sekrestye/kápolna?) csatlakozott. A templomhajóba a D.-i kapun kívül É.-ról is be lehetett jutni. A fő és mellékhajókat 4-4, váltakozó, nyolcszögü kocka, és bimbós, valamint levélornamentikával díszes fejezetű hengeres tagolású pillérköteg választja el. A főszentélyt, a négyezetet és a mellékszentélyeket bordás boltozattal látták el, a hajó és a keresztház síkmennyezetes. ${ }^{27}$ A feltárás során sikerült a középkori járószinteket tisztázni a megemelt szentélyekben és a templomhajóban. A főszentélyben előkerült az oltáralapozás, míg a négyezet és a keresztházak találkozásánál a szentélyrekesztő maradványai. A szerzetesi kórus eredetileg a második pillérpár vonalában záródott. Feltehetően már a református időszakban épült a templom ÉNy.-i sarkánál, a templomtól különálló, É-D.-i irányú emeletes épület, amelyet keskeny körítöfal kötött össze a templommal.

A majki premontrei prépostság feltárását 1982-84 között Juan Cabello végezte. A váradhegyfok fíliájaként alapított Szűz Mária prépostság hiteleshelyként is müködött. A ninivei katalógusban már feltüntetett prépostság alapítója feltehetően a Csák nemzetség trencséni ágát alapító Máté tárnokmester. Pusztulása követően 1733-ban, Esterházy József a kamalduli remeték számára adott alapítólevelében engedélyezte a remeteségtől DK.-re fekvő prépostság maradványainak elbontását. ${ }^{28} \mathrm{~A}$ nagyméretű, $45 \mathrm{~m}$ hosszú, $23 \mathrm{~m}$ széles, 5-5 pillérrel 3 hajóssá osztott, bazilikális alaprajzú, alapozásában félköríves, falában sokszög szentélyzáródású templom hajójának $\mathrm{K}$.-i végéhez mindkét oldalon négyzetes helyiség csatlakozott. A D.-i oldalon épült meg a feltehetően emeleti szinttel is rendelkező, $32 \times 9,5$ m-es, 4 helyiségből álló kolostorépület. A D.-i mellékszentély előteréből előkerült egy vörös mészkőlappal fedett sír, melyet egy II. András dénár keltez. A főszentély sarokpontjain támpillér alapozások találhatók. A nyugati oldalon a föfalak kiszélesedő alapozása toronypár meglétére utal. A prépostság területét körítőfal övezte.

26 Lukács-Cabello-Csengel 1991.16-17.

27 Lukács-Cabello-Csengel 1991. 17. Az ásatók szerint az eredeti tervek szerint a hajót is boltozni akarták, és egy boltszakasszal hosszabbra tervezték de az építkezés során egy tervmódosítás következett be. Ennek bizonyítéka az É.-i mellékhajó Ny.-i végén egy falsíkig visszafaragott boltozatindítás, valamint az É.-i torony előtt feltárt falmaradvány.

28 Csengel 1991. 44-46. 


\section{PREMONTREI PRÉPOSTSÁGOK A KÖZÉPKORI MAGYARORSZÁGON, KÜLÖNÖS TEKINTETTEL A KAPOSFÖI SZENT BENEDEK PRÉPOSTSÁGRA}

A türjei Szűz Mária prépostságot, Csorna filiáját, amely 1268 és 1358 között hiteleshelyként is müködött, a Türje nemzetség tagja, Szentgróti Dénes bán alapította 1230 előtt. Dénes, szlavon bán, később 2 ízben nádor, II. András alatt tűnt fel, majd IV. Béla legbensőbb köréhez tartozott. A 3 hajós, Ny.-i toronypáros, bazilikális elrendezésű templom hajója a tervezettnél rövidebb (2 pillérpáros), nyújtott főszentélye - ami később elpusztult - viszont hosszabb lett. ${ }^{29} \mathrm{~A}$ templomhajót zárókőben végződő, 8 szögletű pilléreken nyugvó, csúcsíves bordás keresztboltozat fedi. 1920-21-ben Lux Kálmán restaurálta, az 1990-es években műemléki kutatását $D$. Mezey Alice végezte, aki a templom északi falán Szt. László legendáját ábrázoló freskót tárt fel. Az Árpád-kori konventépület a maival ellentétben a templom É.-i oldalához épült. Vándor László ásatása során feltárta a szabályos négyszögben zárt monostor alapjait. ${ }^{30}$ 1543-ban Hagymási Eustach kegyúr katonái feldúlták a prépostságot, a templom mellett épült Szt. Anna kápolnát, és a temetöfalat is lerombolták. 1547ben leégett a konvent még megmaradt része, 1566ban pedig a templomot gyújtotta fel a sümegi várnagy. A török ellen castellummá átalakított prépostság a veszprémi végvári rendszer részét képezte.

A gyulafirátóti monostort, Jászó filiájaként, a Boldogságos Szűz tiszteletére 1239/40 táján alapította Rátót nembeli Mátyás érsek. A háromhajós, egyenes szentélyzáródású, kereszthajós, nyugati végében bejárati előcsarnokkal rendelkező templomot késő román - kora gót stílusban építették. A feltárásokat Pámer Nóra folytatta a templom és a korábban pajtává átalakított apátsági épületekben. ${ }^{31} \mathrm{~A}$ templomhoz délkeletről csatlakozó, téglalap alaprajzú, emeletes apátsági épület földszintjén a sekrestye után a káptalanterem, egy $2 \mathrm{~m}$ széles folyosó és az ebédlő helyezkedett el, míg a felső szinten a hálótermek - ahonnan közvetlen átjárást biztosítottak a templomba - kaptak helyet. A káptalanterem nyugati falát 2 enyhén csúcsíves ikerablak közt egy ajtónyílás osztotta meg. A refektórium D.-i falában rakott egy ablaknyílást, Ny-i falán egy széles bejáratot rekonstruáltak. D.-i falának armírozása mutatja, hogy ez egyben végfala is volt az apátságnak. A templom szentélyét $60 \mathrm{~cm}$-el emelték meg a D.-i kapu küszöbszintjéhez képest. A D.-i kereszthajójában a bordás keresztboltozat nyoma még ma is fellelhető.

A mórichidai Szt. Jakab prépostság, Csorna fíliája, 1241-51 között épült és Pók nembeli Móric mester alapítása. A kisebb létszámú kolostorok körébe tartozott, és az alapító temetkezési helyeként, valamint a környék lelkigondozása miatt hozták létre. Fegyverneki Ferenc vizitátor az elnéptelenedett prépostságot megszüntette, 1511-ben pedig Somlóvásárhelyről helyezett ide apácákat, a létszám később Szegedről jött apácákkal bővült. A 18. sz.-ban barokkizálták, 1933ban alakították vissza románkori alakját. ${ }^{32} \mathrm{Az}$ egyhajós, egyenes szentélyzáródású, nyugati toronypárral rendelkező, sarkain támpillérrel megerősített templom csúcsíves diadalívvel, boltozott szentéllyel rendelkezett, amihez D.-röl dongaboltozatos sekrestye épült. A sekrestye DNy-i ajtónyílása, az innen az emeletre vezető lépcső, valamint az itt található résablakok a monostorszárny (dormitorium) emeleti kapcsolatáról árulkodnak. Az elöreugró, fejezet nélküli, csúcsíves tagozattal is rendelkező, bélletes nyugati kapun keresztül lehetett belépni a 3 nyílású karzat alá. Hasonlóan csúcsíves boltozattal rendelkezett a szentély, ahol a 4 sarokban található bimbós levéldíszes oszlopfőkből homorú élszedésű bordák egy Isten kezét ábrázoló zárókőbe futnak össze. A D.-i hajófalban, a padlástérben és a szentély K.-i falában az 1. periódushoz tartozó, keskeny, félköríves ablakok kerültek elő. A kapuépítménybe foglalt, félköríves, D.-i bejárat a szerzeteseknek biztosította a bejárást. Az oromzat csúcsa alatt kereszt alakú résablak az ócsai és bényi templommal rokonitható. ${ }^{33}$

A prépostságok díszítése követi a korszakra jellemző ornamentikát, nem állíthatjuk, hogy bármely, a rendre jellemző lényegi eltérés lenne megfigyelhető a bimbós fejezetek (Bény: Ny.-i kapu jobb oldala, karzat D.-i oszlopfő, Ócsa: É.-i kapu, Jánoshida: D.-i kapu, Zsámbék: D.-i mellékhajó, Türje: hajó D.-i pillér, féloszlopfök, szentély D.-i konzol, Jánoshida: D.-i kapu, Mórichida: szentély oszlopfő), húsos leveles/tölgyleveles ornamentika (Bény: Ny.i- kapu, Ócsa: D.-i kapu, Ság: D.-i kapu, Gyulafirátót: káptalan terem ikerablak osztója), vagy a lóhere díszítésü oszlopfők (Türje: hajó É.-i pillér, Gyulafirátót: kereszthajó falpillér) sorában, azonban kiképzésükben lehetnek lényeges különbségek. Finom kidolgozású csavarodó indákat lehet megfigyelni Zsámbékon (D.-i mellékapszis párkány, föhajó pillérfejezet, rózsaablak), Ócsán (D.-i mellékszentély konzol), és a gyulafirátóti egyik zárókövön. A záróköveket díszíthette forgó levél (Gyulafirátót, Türje), vagy akár Isten keze (Mórichida). Szélfútta húsos levéldíszítés leginkább Ócsára jellemző (négyezet ÉNy-i pillérfö, É.-i mellékhajó, D.-i mellékkápolna fejezet). Még megjelennek a korábbi korszakra jellemző félpalmetta (Türje: hajó, É.-i pillér) és rozetta (Ócsa: D.-i kapu) díszítések. Figurális díszítésű oszlopfőket Bényben (karzat É.-i oszlopfő, vadászat jelenete) Zsámbékon (főhajó pillérfejezet, sárkányküzdelem), kisebb mértékben az ócsai karzat D.-i oszlopfőjén (madarak) D.-i kapuján (sárkány), a jánoshidai D.-i kapun (bimbós fejelezetben rejtőző arcok) valamint a bényi Ny.-i kapu É.-oldalán (levélből kinövő ember) találhatunk. Domborművet egyedül Jánoshidáról ismerünk. Gótikába hajló formát őriz a Mórichidai Ny.-i kapu és diadalív, a sági D.-i kapu, az ócsai főszentély boltozata, a türjei hajó bordás keresztboltozatának íve és főhajójának árkádjai. Oszlopcsonk konzol a türjei (szentély, hajó pillérei) és ócsai (D.-i mellékszentély) templomban került elő. 


\section{A Kaposfői (Szentbenedeki) prépostság}

A korábban felsorolt prépostságokban valamilyen szintű műemléki vagy régészeti kutatás zajlott az elmúlt időszakban, azonban Somogy megye egyetlen, bizonyíthatóan premontrei prépostságában - a kaposfői prépostság területén eddig komolyabb kutatás nem történt. A Barát-dombon már Rómer Flóris által lokalizált, a felszínen csak vízszintesre elplanírozott domboldalként megjelenő valamikori apátság feltárását, az önerőt biztosító helyi önkormányzat és a Porta Pacis lelkigyakorlatos ház, valamint az NKA pályázati finanszírozása révén kezdhette meg 2014-ben a Rippl-Rónai Múzeum. ${ }^{34}$ $A z$ ásatás még folyamatban van, eredményeiről a jövőben számolunk be. Első lépésként a történeti adatok összegyüjtését végeztük el.

A kaposfői prépostság a kései prépostságok körébe tartozott, 1252-ben I. Moys nádor fiai II. Moys és Alexius mesterek alapították Mogorfaluban (Magyarfalu) Szent Benedek tiszteletére. ${ }^{35}$ A monostort adományokkal is ellátták, Kelemenvölgy, Szenna és Patca került a tulajdonába, amit 1254-ben Pat birtokkal (ahol Szt. Kozma és Damján tiszteletére szentelt templom állt) bővítettek. ${ }^{36}$ Kelemenvölgy, illetve a hasonló nevű Kelemenfalva Bárd és Patca vidékén feküdt és a 15. században többször is emlegetik a források $(1456,1483) .{ }^{37}$ Szenna Magyarfalu határosa volt az alapításkor. A 15. században a kaposvári vár tartozéka, illetve a Perneszi és a Laki Thúz családok birtokolták. ${ }^{38} \mathrm{~A} 16$. században Farkasszennáról is értesülünk, ekkor Szenna másik neve Szokoryna volt. ${ }^{39}$ 1542-ben István nevű papja (rector capelle) $1 \mathrm{Ft}$ hadiadót fizetett. ${ }^{40}$ Talán a premontreiek birtoklására utal a falutól Ny-ra fekvő Szent Béni-hegy. ${ }^{41}$ A birtokok közt ugyancsak előforduló Patca/Poczyta a 15 . században az Ipoltfalvi (Lipótfai) családé, azonban 1550-ben Szentbenedekkel együtt írják össze, majd a 16. sz. végén (1598-99) már a Geréczi család kezén találjuk. ${ }^{42}$ A hasonlóképpen adományként említett Pat falut, amely Hetestől DNy-ra, a Pati erdöben feküdt, 1316ban plébániaegyház felével eladták Palyai Luchénak, ami a kegyuraság osztott voltára utal. ${ }^{43}$

A prépostság filiációja bizonytalan, a hilgentáli katalógus szerint Váradhegyfokból alapították, a tongerloi katalógus Túróc, míg az 1320. évi jegyzék Csút filiájaként említi. Ez utóbbi bizonyára helytelen, mivel Csút alapítása (1264) későbbi, mint a kaposföi prépostságé. ${ }^{44} \mathrm{~A}$ prépostság több ízben is előfordult

34 Ásatásvezető: Molnár István középkoros régész

35 CD IV/2. 159, SMM-B. 95. 5. DL 47410, II. Moys a Kaposfői prépostság mellett, ciszterci kolostort is alapított a mai Dombóvár ÉK.-i határában, a Tolna megyei Ábrahámban 1263-ban.

36 SMM-B 95. 6. DL 47410

37 Csánki II- 618

38 Somogy vm. 152.

39 SMM-K. 83. 84. DL 49357 (1507), SMM-B. 93. 29. DL 49364

40 ETE IV. 138.

41 Rómer Jk. LXVI. 63. RRM A. IV/64/1.

42 Csánki II. 634

43 „Porcionem suam a parte septemtrionis situatam cum medietate parochialis ecclesie eiusdem villa Poth." AOM I. 392, SMM-B. 96. 54.

44 Oszvald 1957. 237-238. a forrásokban, 1304-ben, 1318-ban és 1468-ban. ${ }^{45}$ 1342-43-ban Péter, 1415-ben Mátyás, 1449-ben Albert, 1521-ben Ferenc, míg 1540-ben és 1550-ben Mihály prépost nevével találkozunk az oklevelekben. ${ }^{46}$ 1452-3-ban a kaposfői prépost több telket adott el Perneszi Pálnak. 1492-ben II. Ulászló megerősíti Gereczi Antalt az ősei által alapított prépostság feletti kegyúri jogaiban. ${ }^{47} 1540$-ben a kegyurak a prépostságot kirabolták, javait elvitték. ${ }^{48}$ 1550-ben Mihály prépost, aki korábban a Türjei prépostságból lett kihelyezve, korára való tekintettel és a töröktől való félelme miatt kérvényezi visszatérését. A prépostságot 1552-ben pusztította el a török. ${ }^{49}$

A prépostság maradványai a mai Bárdudvarnok területén, a Bárdi-pataktól és a valamikori vasúttól (ma bicikliút) K.-re, egy $60 \times 30$ m-es mesterségesen elplanírozott domboldalban találhatók. Rómer Flóris leírása alapján szentélye 4,5 m széles, hajójának hossza kb. 20-24 m volt, és a kolostorépületek a templomtól D.-re feküdtek. Az együttest kőfal kerítette, melyet Fürsatz lelkész bontott el házépítés céljából, míg az 1770 körül épült r.k. templom építéséhez is hordtak el téglákat. ${ }^{50}$

\section{A prépostságot alapító család}

Az alapító család első ismert tagjának, I. Moys (Majos) nádornak (1228-1231) és fivérének, Miklós vasi ispánnak a felemelkedése II András uralkodása alatt kezdődött, és igazából I. Moys fiának, II. Moysnak az idején teljesedett ki. Miklós ez idő tájt tett szert a Felsőlendvai uradalomra, ahol a család 1271 előtt várat is épített. ${ }^{51} \mathrm{~A} 13$. sz. második felében a család megszerezte a Dárói uradalmat, ahol Dárói Salamon (1273-1308) várépítése nyomán egy $20 \times 50$ m-es, kettős árokkal övezett téglalap alakú erősség figyelhető meg a mai napi Jágónak határában, a Kapos folyó déli partján. Másik várbirtokuk az ugyancsak Tolna megyei Egervár (Háb), ahol a Gereci ághoz tartozó Sándor fia Majos tornya állt. ${ }^{52}$ I. Moys, II. András és fia, Béla közti vitában jól helyezkedve, oly sikeresen mentette át a család befolyását, hogy fiának királyi családba tartozó

45 SMM-B. 92. 10. DL 49230, ZO I. 159., SMM-B 94. 33. DL 49335

46 SMM-B 2001. 51, DL 47410, SMM-B 94. 28. DL 49323, Kovács 2002. 39., Rupp I. 298-9.

47 Csánki II. 643., Oszvald 1957. 245. „Totum et omne ius patronatus prepositure ecclesie Sancti Benedicti ordinis fratrum premonstratensium, in possessione Zenthbenedek vocata, per progenitores eiusdem magistri Anthonii de Gerech dotate, quod quidem ius patronatus iidem progenitores ipsius magistri Anthonii a primeva ipsius pepositure fundatione habuerunt."

48 Kovács-Legeza 2002. 39.

49 Kovács-Legeza 2002. 39

50 Pesty 2001. 299., Rómer 1876. 2. 5., Rég. Füz. II/13. 64., RRM A. IV63/20.

51 Engel 1996. 312, 57, 106, 125, 127, 207, 359, 479. Unokája, Salamon a család birtokainak súlypontját áthelyezi Tolna megyébe, így 1275-ben Lendvát eladja a Gútkeled nembeli Amádénak. Salamon unokái, Péter és Miklós Nagy Lajos alatt még jelentősebb befolyással bírnak az udvarnál (Péter barsi, csongrádi, tolnai, fejéri ispán, lévai várnagy, királynéi lovászmester és testvérével együtt udvari lovag), azonban a későbbiekben háttérbe szorul a család.

52 Engel 1996. 308. Ezt a Kaposszekcső K.-i részén álló erősséget III. András elkobozta 1296-ban, azonban 1417-ben újból a család birtokai közt sorolták fel. 


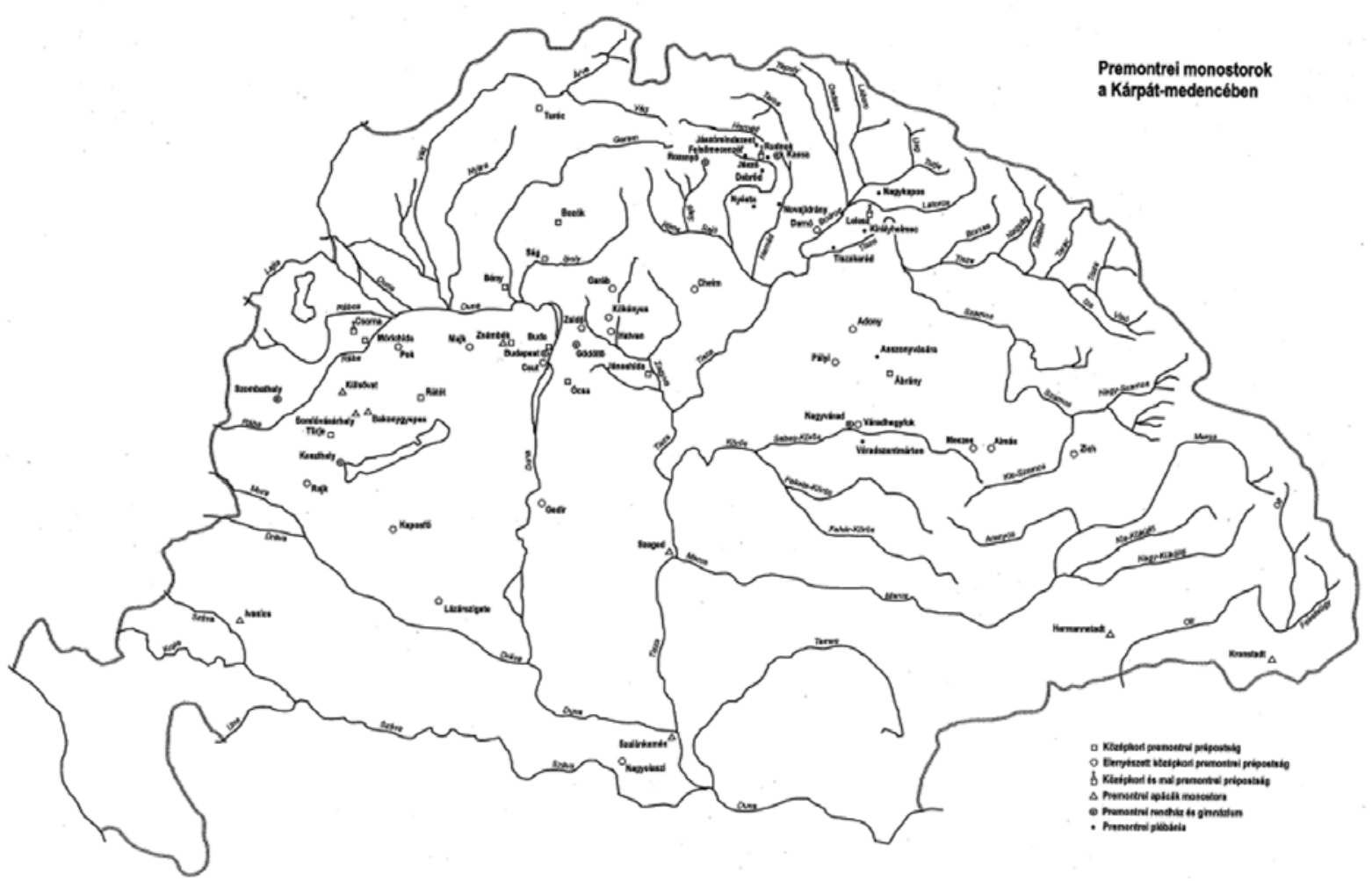

3. ábra. Premontrei prépostságok elterjedése a történelmi Magyarország területén (Kovács-Legeza nyomán)

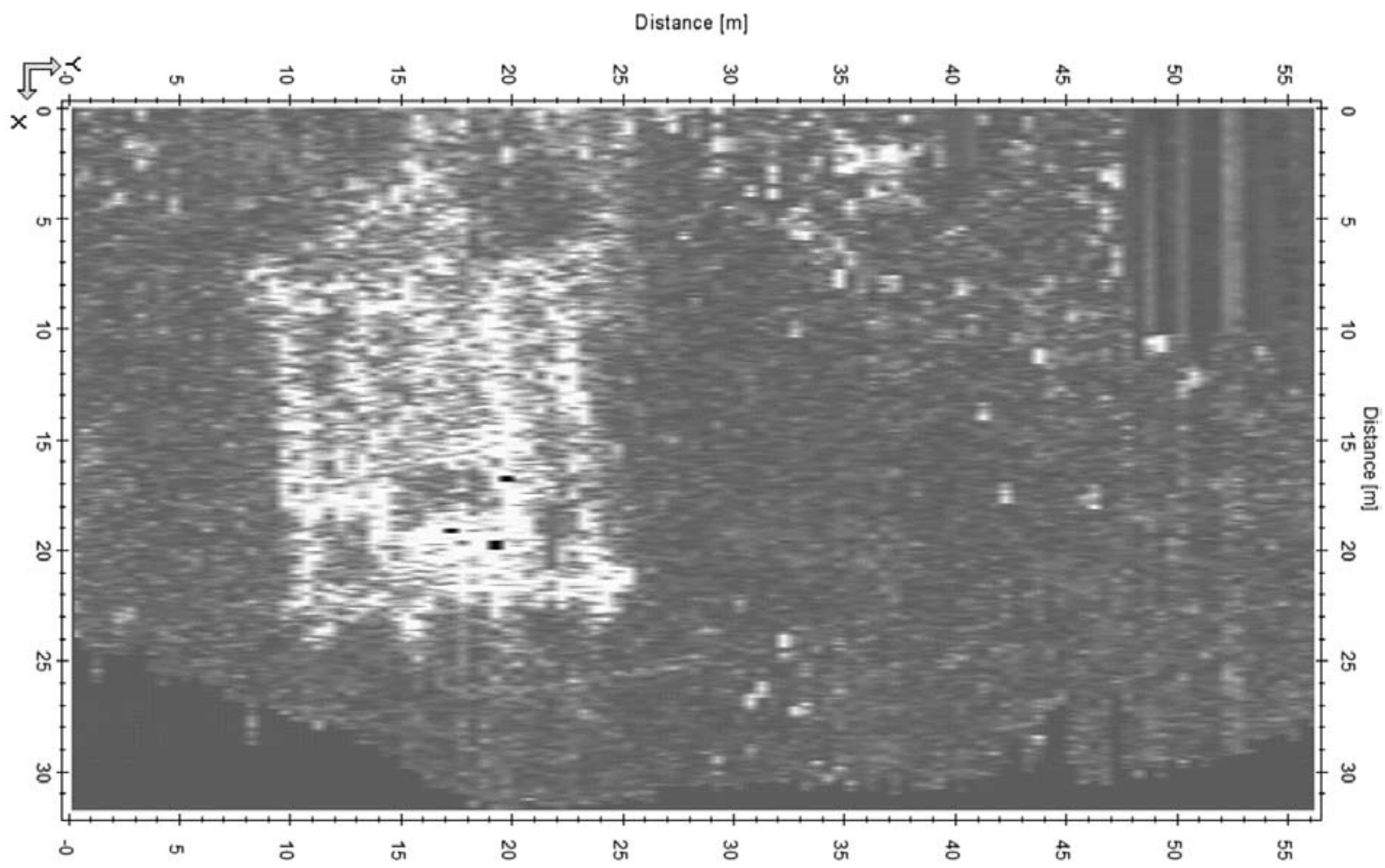

4. ábra. A kaposföi prépostság talajradaros vizsgálatának eredményei. 
feleséget is sikerült szereznie. ${ }^{53}$ II. Moys 1280-ban bekövetkezett haláláig így a korra jellemző főúri életpályát futhatott be - az 1250-es évektől kezdődően előbb lovászmester, asztalnok, somogyi, varasdi föispán, szlavón bán, Béla herceg, majd királynéi tárnokmester, nádor és országbíró. Lányait befolyásos főurakhoz adta, így került rokoni viszonyba a Pók nembeliekkel és a Kőszegiekkel. A hasonló életpályát befutó apóstárs, Pok nembeli II. Móric a Sajó menti ütközetben tünt ki. Ő volt az aki a királyt megmentette a csata során, és aki menekülése során Dalmáciába is elkísérte. ${ }^{54}$ Felesége révén a Rátót nembeliek is a rokonság sorába tartoztak, és itt kell megjegyeznünk, hogy mindkét másik család ez idő tájt alapított prépostságot, Mórichidán és Pokon, illetve Gyulafirátóton. ${ }^{55} \mathrm{E}$ sikeres politikát Sándor fia Moys már nem tudta sikerre vinni, mikor csatlakozott Borsa Kopasz nádor felkeléséhez Károly Róbert ellenében. A család a 13. század végén bomlásnak indult, a Tolna megyei Dárói ág mellett, Somogyban a Gereczi család lett a birtokos és egyben a prépostság kegyura is.

53 Egyes kutatók szerint Moys felesége, IV. Béla lánya, Szabina, míg mások szerint $\mathrm{V}$. István feleségének, Kun Erzsébetnek hasonnevű rokona volt.

54 Kádár 2013. 136. Érdekesség, hogy II. Móric atyja, I. Móric, I. Moyshoz hasonlóan az 1220-as évektöl kerül fontosabb tisztségekbe.

55 Pok nembeli Móric mester alapításai: Pok 1234-1251 között, Mórichida 1241-1251 között, Rátót nembeli Mátyás esztergomi érsek alapítása: Gyulafirátót 1239-1240 között.

\section{Eredmények}

Az ásatást megelőzően elvégeztük a prépostság feltételezett helyének talajradaros vizsgálatát. ${ }^{56} \mathrm{~A}$ vizsgálat a kiegyenlített domboldal É.-i felében egyértelmüen kirajzolta $220 \mathrm{~cm}$ mélyen a prépostsági templom megközelítöleg 23×15 m-es méretét, három hajós, nyugati toronypáros alaprajzát. $\mathrm{A} \mathrm{Ny}$.-i oldalt láthatóan támpillérekkel erősítették meg. A K.-i oldalon a szentély nyoma bizonytalan, mint ahogy a templomhoz DK.-ről csatlakozó rendház alaprajza is nehezen követhető ebben a mélységben. Sekélyebb mélységen (70-100 $\mathrm{cm}$ ) azonban láthatóvá válik egy D.-i többosztatú csatlakozó szárny. Feltehetően a prépostsági épületek sekélyebb alapozással készültek a minden bizonnyal kis létszámú szerzetesek számára.

$A z$ ásatás során reméljük többet tudhatunk meg Somogy megye sokáig megbúvó premontrei prépostságáról, és eredményeink hozzájárulhatnak a magyar premontrei rendházak középkori történetének, mủvészetének jobb megismeréséhez.

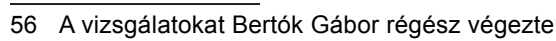

\section{Irodalom}

Borovszky S. és CsÁNKı D. 1914: Magyarország vármegyéi és városai. Somogy vármegye. 1914. Budapest. (Somogy vm.)

BorsA I. 1992, 1994: A Mérey család levéltára. I., III. In: SMM. 23, 25. 1992, 1994. Kaposvár. 3-28., 23-50. (SMM-B. 92, 94.)

BORSA I. 1993: A somogyi konvent II. Ulászló-kori oklevelei az Országos Levéltárban. In: SMM. 24. 1993. Kaposvár. 27-30. ((SMM-B. 93.)

BorsA I. 1995, 1996, 2001: A somogyi konvent oklevelei az Országos Levéltárban. In: SMM. 26, 27, 32. (1995, 1996, 2001.) Kaposvár. 1995. 3-18. (1215-1300); 1996. 49-68. (1301-1330); 2001. 7-78. (1401-1420). (SMM-B. 95, 96, 2001.)

CSÁNKı. 1890: Magyarország történeti földrajza a Hunyadiak korában. I-III., V. 1890-1913. (IV. Fekete Nagy Antal, 1941.) II. Somogy megye. 1890. Budapest

Csengel P. és Cabello, J. 1991: A majki premontrei prépostság feltárása. Műemlékvédelmi Szemle 1991. 2. 44-46

D. Mezey A.1992: Türje (TKM) Budapest. 1992

Egyháztörténeti emlékek a magyar hitújítás korából. I-V. 1902-1912. Budapest (ETE)

ENGEL P. 1996: Magyarország világi archontológiája 1301-1457 I.-II. Budapest 1996.

FEJÉR GY.1829-1844: Codex diplomaticus Hungariae ecclesiasticus ac civilis. I-XI. 1829-1844. Buda-Budapest (CD)

HABOvstiAK, A. 1966: Frühmittelalterliche Wallanlage und romanische Bauten in Bina. Nyitra, 1966.

Ipolyı A., Nagy I., Paur I., Ráth K. és VéGhely D. (szerk.) 1865-1891: Hazai Okmánytár / Codex diplomaticus patrius. I-VII. 18651891. Győr (HO)
KÁDÁR T. 2013: Egy érdekes bárói életpálya a 13-14. sz. fordulójáról: Pok nembeli Móric fia „Meggyesi” Miklós erdélyi vajda. In: Acta Universitatis Debreciensis Series Historica LX. Történeti Tanulmányok XXI. 2013. 133-155.

Kocztur É. 1963: Somogy megye régészeti leletkatasztere. Régészeti füzetek. II/13. 1-163. (Rég. Füz. II/13)

КомJÁthY M. 1983: A somogyi konvent II. Ulászló-kori oklevelei az Országos Levéltárban. In: SMM. 14. 1983. Kaposvár. 82-88. (SMM-K. 83.)

Kovács I. E. és Legeza L. 2002: Premontreiek. (Szerzetesrendek a Kárpát-medencében). Budapest 2002.

KozÁK K. 1973: A premontreiek építkezései Győr-Sopron megyében. - Arrabona 1973. 125-148

KozÁK K.1974: A jánoshidai rk. templom, volt premontrei prépostság régészeti kutatása 1970-1974, Jász Múzeum Jubileumi Emlékkönyve, Jászberény, 1974. 277-322.

KozÁK K. 1985: Jánoshida. Plébániatemplom (TKM) Budapest 1985.

LukÁcs Zs., Cabello, J. és Csengel P. 1991: Az Ócsai premontrei prépostság kutatása, Múemlékvédelmi Szemle 1991. 1. 16-19.

Mezey L. 1963: Csútmonostor alapítástörténete és első oklevelei. Tanulmányok Budapest Múltjából. XV. 1963. 7-42.

NAGY I., NAGY I. és VÉGhely D. (szerk.): Zichy Okmánytár. A Zichi és Vászonkeői Gróf Zichy család idősb ágának okmánytára. (Magyar Történelmi Társulat.) I-XII. 1871-1931. Pest-Budapest (ZO)

NAGY I. és TASNÁDI NAGY Gy. (szerk.) 1878-1920: Codex Diplomaticus Hunagricus Andegavensis (Anjou-kori Okmánytár). I-VII. 18781920. Budapest (AOM) 
Oszvald A. 1939: A magyarországi középkori premontrei prépostságok. Budapest 1939.

Oszvald F. A. 1957: Adatok a magyarországi premontreiek Árpád-kori történetéhez, Művészettörténeti Értesítő VI. 1957. 231-254.

PÁmER NóRA 1967: A gyulafirátóti középkori premontrei monostor feltárása VMMK. 1967. 239-246.

PESTY F. 2001: Somogy vármegye helynévtára. Fontes Comitatus Simighiensis. 1. Szerk. Bősze Sándor. 2001. Kaposvár

Rippl-Rónai Múzeum Adattára (RRM A.)

RÓMER F. 1876: Román és átmenetkorú építmények hazánk területén. Arch. Közl. 1876
RÓMER F. Jegyzőkönyvei (Rómer Jk.)

Rupp J.1870-1876: Magyarország helyrajzi története fő tekintettel az egyházi intézményekre, vagyis a nevezetesb városok, helységek és azokban létezett egyházi intézetek püspökmegyék szerint rendezve. I-III. 1870-1876. Pest-Budapest

SISKA J. 2001: Premontrei szerzetesek a Bodrogközi Leleszen. HOMÉ XL. Miskolc 2001. 287-296.

VALTER I. 1991: Újabb régészeti kutatások a Zsámbéki premontrei prépostsági romban 1986-1991. Müemlékvédelmi Szemle 1991. 2. 24-28.

VALTER I. 2004: Árpád-kori téglatemplomok Nyugat-Dunántúlon. Budapest 2004. 68.

\title{
Premonstratensian monasteries in medieval Hungary with special regards to the S. Benedict provostry of Kaposfö
}

\author{
CSILLAARADI
}

Though the foundation of Premonstratensian monasteries covers a somewhat short interval - ranging from the probable foundation of Váradhegyfok (1130) to that of the abbey of Csút (1264) an about 40 provostries were established - but the role played in Hungarian ecclesiastical life was significant, as in addition to their monastic activities they took part in the pastoral life as well as performing chancellery functions (loca credibilia). Though their roots were different (royal, noble, Episcopal foundations) they established an intense relationship through filiation, so it was not uncommon that the new provost was chosen from the members of the mother monastery.

The monument and archaeological research gave evidence to a much varied layout, but there are certain connections in typology which can be based on fam- ily links between founders. The archaeological excavation of the only Norbertine foundation in Somogy county - the S. Benedict Provostry situated in present Bárdudvarnok - started in 2014. The monastery was founded in 1252 by II. Moys and Alexius in Mogorfalu, while the patronage was later practiced by the related Geréczi family. The family members administering high offices in the period of II. András and IV. Béla held a wide range kinship with other prominent families, such as the Pók and Rátót clan who raised Norbertine monasteries in the same period. The ground penetrating radar inspections performed preliminary to the excavations recorded a $23 \times 15 \mathrm{~m}$ long three naved church with twin Western towers, with presumably adjoining monastic buildings from the SE. 
